\title{
Thoughts on Promoting the Integration of Industry and Education in Local Universities against the Background of New Engineering
}

\author{
Xuehua Jiang \\ School of Automation and Electrical Engineering \\ Linyi University \\ Linyi, China \\ jxhyx@163.com
}

\author{
Peijiang Chen \\ School of Mechanical and Vehicle Engineering \\ Linyi University \\ Linyi, China \\ chenpeijiang@163.com
}

\begin{abstract}
The integration of industry and education is an important measure for the transformation and development of local undergraduate colleges and universities, and also a way to improve the quality of applied talents training. In order to promote the construction of "new engineering subject", local colleges and universities should take the initiative to connect with the regional economic development and industrial transformation, take proactive and effective measures, update the educational concept, optimize the curriculum system, and strengthen the cooperation between schools and enterprises. In so doing, we can construct an educational platform and a guarantee mechanism of "industry and teaching cooperate with each other to perform education", run through the whole process of talent training, and explore a new mode of talent training in local undergraduate colleges and universities, thereby meeting the requirements of the construction of "new engineering subjects".
\end{abstract}

Keywords-Local undergraduate colleges and universities; New engineering subject construction; Integration of production and education; Training model

\section{INTRODUCTION}

The construction of "new engineering subject" puts forward new requirements for the cultivation of engineering talents, and also points out the direction of how to reform and innovate the talent training mode in colleges and universities facing "new engineering subject". In promoting the construction of "new engineering subject", local colleges and universities should take the initiative to connect with regional economic development and industrial transformation, construct the guarantee mechanism of integration of industry and education, and run through the whole process of talent training. This paper explores a new mode of talent training in local colleges and universities to meet the requirements of the construction of "new engineering subjects".

The integration of industry and education is the basic way

This study was supported by the Education Project of Industry-university Collaboration of the Ministry of Education in 2017 (No. 201702141001), the Undergraduate Teaching Reform Project of Shandong Province Higher Education in 2018 (No. M2018X062), and the Teaching Quality Engineering Projects of Linyi University in 2016, 2017 and 2018. to develop the classification, connotation, transformation and cooperation of higher education in our country [1]. It will become the new normal of the teaching reform of higher education in our country at present, and it will promote the development of higher education. It is also an important way for local colleges and universities to transform and develop and deepen the teaching reform. As far as the local undergraduate colleges are concerned, first of all, we should improve the understanding of the integration of industry and education, take the integration of industry and education as one of the basic concepts of running a school, deeply study the background, significance and implementation path of the integration of industry and education.

Consciously combine talent training with social demands, adhere to the concept of serving the needs of local economic and social development. This paper gives full play to the advantages of both sides of the cooperation between schools and enterprises, realizes mutual benefit and win-win, constructs a new mode of "cooperation between schools and enterprises, integration of production and teaching, and cooperation in educating people", and explores the effective ways of cultivating applied talents in local universities.

\section{THE NECESSITY OF PROMOTING THE INTEGRATION OF INDUSTRY AND EDUCATION IN LOCAL UNIVERSITIES}

\section{A. Promoting the connection between local colleges and universities and local economy and society}

Local colleges and universities are fully open to running schools, according to their own services oriented to the initiative and local governments, enterprises and industries to communicate and establish cooperative relations. To jointly build and share open school resources through diversified cooperation among schools, enterprises and schools, so that local governments and industry enterprises can deeply participate in the whole process of personnel training, jointly build and share practical bases, and jointly design talent training plans [2]. Enterprise personnel undertake the task of course teaching and practice teaching, and form a sustainable development mechanism of "platform constructing, resource 
sharing and achievement sharing" through the implementation of integration of production and teaching. Schools should organize forces, take the initiative to investigate and study the needs of local economic and social's development, and understand the talent needs of enterprises.

\section{B. Promoting local colleges and universities to promote the development of local emerging industries}

The construction of "new engineering subject" requires colleges and universities to play a leading and promoting role in scientific and technological innovation and the development of new industries. The integration of industry and education is not only the fundamental path for the cultivation of applied talents, but also the booster of industrial transformation and upgrading and innovation driving development. In order to achieve the goal of "mutual benefit and win-win", to fully mobilize the enthusiasm of local governments, enterprises and industries to promote the integration of industry and education, local colleges and universities should set up the concept of serving local industry development, and in the process of implementing the integration of industry and education, make full use of their own advantages of intelligence and talent, set up corresponding R \& D institutions around the needs of local emerging industries, and carry out targeted research on applied technology research, promote the development of local emerging industries [3].

\section{Promoting local colleges and universities to deepen educational and teaching reform}

Through the integration of industry and teaching, local colleges and universities establish a new mechanism of teaching work and talent training, guide and promote the overall implementation of education and teaching reform in schools, and improve teaching quality. The first is to drive curriculum reform with social and economic development and industrial and technological progress, integrate related professional basic courses, backbone courses, core courses, professional skills application and experimental practice courses, optimize the curriculum system, and focus on cultivating students' professional spirit, professional ability and innovative entrepreneurial ability; The second is to take the cultivation of students' ability as the core, to select and integrate teaching contents, to optimize the teaching content with enterprise production technology and service items, to make it suitable for the actual job requirements of the enterprise; The third is to reform the teaching method according to the actual process of the enterprise, comprehensively promote case teaching, project teaching.

\section{Promoting local colleges and universities to improve the quality of the cultivation of applied talents}

In order to improve the training quality of applied talents, local undergraduate colleges and universities must realize four "changes" in school-running ideas: to serve the local economic and social development, and to transfer to the cooperation between schools and enterprises integrating industry and education, to transfer to the cultivation of applied technology and skilled talents, to enhance students' ability to employment and entrepreneurship[4-5]. As the symbol of the transformation from local undergraduate colleges and universities to application-oriented colleges and universities, the integration of production and teaching through further defining the orientation of running a school, adjusting the specialty setting, improving the teaching quality, strengthening applied research, raising the level of teachers, etc. It is emphasized to reform the curriculum system with competence as the core, to organize teaching activities guided by practice, and to implement research-production cooperation education with application as the main line.

\section{PRoBlems IN PROMOTING THE INTEGRATION OF INDUSTRY AND EDUCATION IN LOCAL UNIVERSITIES}

\section{A. The specialty training scheme and the implementation of the integration of industry and education do not fit in with each other}

Local colleges and universities are used to organizing teaching activities in traditional ways, such as disciplines, specialties, courses, etc., the specialty setting does not connect with the industrial chain of enterprises, and the teaching activities do not connect with the production process of enterprises. Courses based on theoretical knowledge account for a large proportion, and only some courses based on practice and design are mostly formalistic and do not give full play to the expected results; the contents of the courses are old and does not match with the production needs of enterprises. It is not close enough to meet the needs of the development of modern engineering technology [6].

\section{B. The cooperation between schools and enterprises has not reached the level of integration of industry and education}

The depth and breadth of the cooperation between universities and enterprises are directly related to the quality of talent training and the realization of social functions of higher vocational education. However, at the present stage, local applied undergraduate colleges and universities in China are in the reform stage of transformation and development. The cooperation between schools and enterprises is mainly limited to the establishment of student's practice bases, order-type training, on-the-job internships, etc. But the actual participation of enterprises in the training of talents is very low, and local universities and colleges rarely listen to the needs of enterprises. This has led to the disconnection between the technical talents trained by schools and the actual needs of enterprises. The depth and breadth of cooperation between schools and enterprises is not wide enough.

\section{The construction of "double-qualified" teachers lags behind}

The integration of industry and education requires both schools and enterprises to build a high level teaching staff with double qualifications. Many local colleges and universities that have been undergoing transformation and development have realized this problem and taken various measures to build a "double-qualified" contingent, but from the point of view of the status quo is not optimistic. Many local colleges and universities have just changed from ordinary colleges and universities to application-oriented colleges and universities. 
The original teachers are mainly based on theoretical teaching, unable to adapt to the training of practical talents such as experiments and practices, let alone the industry and enterprises jointly carry out scientific research such as the application-oriented scientific and technological research, to serve the local social and economic development capacity is limited.

\section{Absence of quality assurance and evaluation systems}

At present, local undergraduate colleges and universities are lack of quality standard and standard management system suitable to the integration of production and teaching, such as professional setting, teacher team building, laboratory construction, classroom teaching, practical practice and graduation design. Even if some schools have established management system and quality standard, there are still some problems in the process of implementation. Taking graduation internships as an example, many college students practice for up to one year, but how to effectively manage student internships, especially decentralized practice, how to define the responsibilities of college and enterprise guidance teachers, how to evaluate the effectiveness of practice, and so on. These questions aren't there yet. There is a very good solution.

\section{THE COUNTERMEASURES AND SUGGESTIONS TO} PROMOTE THE INTEGRATION OF PRODUCTION AND TEACHING IN APPLIED UNDERGRADUATE COLLEGES AND UNIVERSITIES

\section{A. Raising awareness and establishing the concept of integration of industry and education}

In order to meet the needs of the development of new economy, new technology and new industry in the process of promoting the construction of "new engineering subject", local undergraduate colleges and universities, in order to set up the concept of integration of production and education, we must establish an open, integrated and innovative personnel training system. Take active and effective measures to change the educational concept, optimize the curriculum system, strengthen the construction of teachers, reform teaching methods, pay attention to the cooperation between schools and enterprises, cooperate to educate people, build the platform of integrated education between industry and education, and implement the whole process of talent training [7].

\section{B. Revise and optimize the talent training programme}

In order to improve the quality of applied talents training, it is necessary to revise and optimize the talent training scheme which adapts to the construction of "new engineering subject", and to establish the system of professional steering committee with the participation of industry and enterprise, so as to guide the formulation of talent training plan. We should seek and listen to the opinions and suggestions of experts in the industry and enterprises in view of the personnel training specifications, professional core competencies, curriculum settings, etc., and introduce the professional qualification conditions into the personnel training specifications in a proper and timely manner. This paper introduces the industry standard in the professional core competence identification and the enterprise product production technology in the specialty core curriculum setting, and makes the three elements mutually set off and coordinates with each other. To promote "fusion" education teaching mode, in the establishment of the talent training scheme to cultivate applied talents for the standard, adhering to the forefront of the industry and industry demand, update teaching content, so that the students can understand the discipline frontier knowledge, grasp the latest dynamic information of the industry, in order to highlight the application as the main line, pay attention to cultivating the students' professional ability, comprehensive ability and innovation ability; at the same time, in the training program, we should also establish the matching mechanism between local industry and school specialty qualification certification, In order to make the talent training and post demand docked, to cultivate the post ability as the core, according to the knowledge, ability and quality of the job requirements of the allocation of courses, reasonable arrangements the class hours of each class group, and make each curriculum group effective convergence.

\section{Establishment of practical teaching base outside school with integration of production and teaching}

The construction of practical teaching base is difficult, and the shortage of construction quantity is one of the important factors that restrict the quality improvement of practical talents training in local colleges and universities. Through the deep integration of production and teaching, local colleges and universities can construct knowledge education system, technical skill training system and experimental practice environment according to the requirements of combining work and learning, integrating knowledge and practice, and according to the real technology and process of production and service. In accordance with the advanced technical level of the industry served by the local undergraduate colleges and universities, the construction of experimental training practice bases can be accelerated through joint venture investment or donation, co-construction and leasing of enterprises and so on.

\section{Promoting the implementation of the integrated teaching mode of industry and education}

According to the talent training plan, organize and implement the training process in which the school is the main body and the enterprise participates in the whole process. In the teaching of specialized courses, we can actively promote the "combination of work and study" and carry out teaching in the form of projects, while conducting professional cognition, analysis of employment situation, career planning and employment guidance education for students. May "the enterprise lecture hall" the way, by the enterprise technical and the management personnel to hold the special topic lecture to the school, or organizes the student to the enterprise, under the specialized personnel instruction visits the inspection; practical training courses can be offered to students with tutors from the enterprise who are sent to school or to students in the enterprise "face to face" the teaching of "hand in hand". To establish a student-centered teaching model, advocating the combination of work and learning, the seamless connection between the school learning stage and the off-campus practice stage, professional training, engineering training and post training highly integrated. From the examination of "knowledge mastery" to the "knowledge application", the students' 
knowledge application and problem-solving ability are assessed in the simulation or real situation, so that the students can realize the sense of achievement after completing the task and stimulate their enthusiasm for learning.

\section{E. Promoting the construction of "double type" teachers}

The "double-qualified" teaching team is the premise of implementing "integration of production and teaching, cooperation of education" in local colleges and universities. In accordance with the principle of "not asking for all, but for what to use", we should set up a mechanism for mutual use and flexible mobility of talents between schools and enterprises, speed up the construction of the "double-qualified" teaching staff in local undergraduate colleges and universities, and to solve the problem of insufficient number of double-qualified teachers in the cultivation of applied talents in local undergraduate colleges and universities: On the one hand, schools can actively introduce industry experts, hire outstanding professional and technical personnel from enterprises, and take part in professional construction and parttime teachers with managerial and highly skilled personnel; on the other hand, schools can plan to send teachers to joint ventures for training and transfer Work and practice exercise to improve the practical ability of school teachers.

\section{F. Constructing the operation mechanism to ensure the Integration of production and education}

If the cooperation between local applied undergraduate universities and enterprises is to be more in-depth and lasting, a long-term mechanism of "cooperation between schools and enterprises, integration of industry and education, mutual benefit and win-win situation" must be established, and "cooperative development of enterprises and schools" must be established. Deep integration of industry and education, cooperation and development of coordinated linkage mechanism, construction of talent training mode of integration of industry and education and guarantee mechanism of teaching operation. Through good operation mechanism and cooperation platform, developing inter-school cooperation, integration of industry and education, cooperation between schools and enterprises, cooperation between colleges and trade associations and scientific research institutions, it can optimize the allocation of resources, realize resource sharing, and highlight professional characteristics. Give full play to group advantage and scale advantage.

\section{CONCLUSIONS}

As an important part of higher education system, local undergraduate colleges and universities shoulder the important mission of cultivating high-quality applied talents and serving the development of regional economy and industry. Applied talents are the embodiment of the core competitiveness of a country's industry, and the basic orientation of the cultivation of applied talents is oriented to production, construction, management and service to train technical applications and innovative talents. With the development of technological innovation and industrial upgrading, the demand for applied talents will be more and more large in the economic society, and the quantity of applied talents should be increased and the quality of applied talents should be improved. Therefore, the integration of industry and education is not only the need of cultivating applied talents in local colleges and universities, but also the need of the characteristic development of local colleges and universities. To establish a long-term mechanism for the integration of industry and education, carry out comprehensive and in-depth integration in the fields of personnel training, project research and development, and resource sharing, and deepen the reform of the training mode of applied talents, and to promote the scientific development of local undergraduate colleges and universities and to improve the level of practical personnel training.

\section{ACKNOWLEDGMENT}

This study was supported by the Education Project of Industry-university Collaboration of the Ministry of Education in 2017 (No. 201702141001), the Undergraduate Teaching Reform Project of Shandong Province Higher Education in 2018 (No. M2018X062), and the Teaching Quality Engineering Projects of Linyi University in 2016, 2017 and 2018.

\section{REFERENCES}

[1] G. Wang, F. Zhang, The Exploration of Construction Industrial College by Local Universities in the Background of the Emerging Engineering Education: a Case Study of Prefabricated Structure Industrial College in Fujian Jiangxia University, Journal of Fujian Jiangxia University. 7, (6) (2017) 109-115.

[2] X. Meng, D. Wang, L. Jiang, Deepening School-enterprise Cooperation and Enterprise to Improve Teachers' Practical Ability Strategy of Applied Undergraduate College, (36) (2018) 33-35.

[3] P. Chen, Study on Current Situation Analyzing and Countermeasure of Innovative Ability Education of College Students, 3rd International Conference on Education and Social Development (ICESD 2017), Xi'an, China, (2017) 500-504.

[4] F. Gong, Research on Mode of Applied Talents Training in Local Undergraduate Colleges and Universities Based on the Perspective of "Integration of Production and Education", Journal of Changchun University. 28, (4) (2018) 46-49.

[5] X. Jiang, X. Pan, P. Chen. Reflections on the Integration of Innovative Entrepreneurship Education and Professional Education, Advances in Social Science, Education and Humanities Research, 176 (2018) 10031007.

[6] Y. Huang, Curriculum Construction in Local Universities Under the Background of Integration of Production and Education 2.0, Journal of Shangluo University. 32, (2) (2018) 37-40.

[7] Z. Zhang, L. Chen, Deepening the Integration of Production and Education in Application-oriented Universities, Journal of Luoyang Normal University. 37, (5) (2018) 69-71. 